\title{
Bt cotton seed purity in Burkina Faso: status and lessons learnt
}

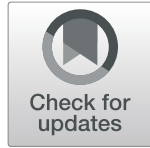

BOURGOU Larbouga', KARGOUGOU Ester ${ }^{2}$, SAWADOGO Mahamadou ${ }^{3}$ and FOK Michel ${ }^{4,5^{*}}$ (D)

\begin{abstract}
Background: Since the commercial release of Bt cotton in Burkina Faso in 2009, the issue of seed purity in producers' fields has rarely been addressed in an unbiased and objective manner. The potential for contamination of conventional seed varieties with Bt traits and the consequent threat to the continuation of organic cotton production has been documented. However, studies are rare on the varietal purity of Bt cotton seeds, despite the implications for the effectiveness and sustainability of their use.

This paper compensates for the lack of research on the varietal purity of cotton seeds in Burkina Faso by reporting the results of Enzyme linked immunosorbent assay tests collected in 2015 on samples of both conventional and Bt varieties from 646 fields.

Results: According to the conservative criteria used to declare the presence of a Bt gene in a given variety (more than $10 \%$ of seeds of conventional variety exhibit Bt traits, and at least $90 \%$ of seeds of Bt variety exhibit Bt traits), seed purity was very questionable for both types of variety. For the supposedly conventional variety, the CrylAc gene was observed in $63.6 \%$ of samples, the Cry2Ab gene was observed in $59.3 \%$ of samples, and both genes were detected in $52.2 \%$ of the seed samples. Only $29.3 \%$ of the seeds that were supposed to be of conventional type contained no Bt genes. Conversely, for the labeled Bt variety, the Cry 7 Ac gene was found in only $59.6 \%$ of samples, the Cry2Ab gene was found in 53.6\% of the samples, and both genes were found in $40.4 \%$ of the samples. Finally, for the seeds that were supposed to contain both genes (Bollguard 2), both Cry $1 A c$ and Cry2Ab genes were found in only $40.4 \%$ of the samples, only one of the genes was found in $32.4 \%$ of the samples, and $27.2 \%$ of the seeds in the samples contained neither.

Two factors are responsible for the severe lack of seed purity. First, conventional varieties are being contaminated with Bt traits because of a failure to revise the seed production scheme in Burkina Faso to prevent cross-pollination. Second, the original Bt seeds provided to Burkina Faso lacked varietal purity.

The organic sector plays a very minor role in the cotton sector of Burkina Faso (production of organic cotton totaled $453 \mathrm{t}$ in 2018/2019, out of national cotton production of $183000 \mathrm{t}$ ). Nevertheless, the lack of purity in conventional seed varieties is a threat to efforts to expand certified organic cotton production. The poor presence of Bt proteins in supposed Bt varieties undermines their effectiveness in controlling pests and increases the likelihood of the development of resistance among pest populations.

(Continued on next page)
\end{abstract}

\footnotetext{
* Correspondence: michel.fok@cirad.fr

${ }^{4}$ CIRAD, F-34398 Montpellier, France

${ }^{5}$ UPR AIDA, Univ Montpellier, Montpellier, France

Full list of author information is available at the end of the article
}

(c) The Author(s). 2020 Open Access This article is licensed under a Creative Commons Attribution 4.0 International License, which permits use, sharing, adaptation, distribution and reproduction in any medium or format, as long as you give appropriate credit to the original author(s) and the source, provide a link to the Creative Commons licence, and indicate if changes were made. The images or other third party material in this article are included in the article's Creative Commons licence, unless indicated otherwise in a credit line to the material. If material is not included in the article's Creative Commons licence and your intended use is not permitted by statutory regulation or exceeds the permitted use, you will need to obtain permission directly from the copyright holder. To view a copy of this licence, visit http://creativecommons.org/licenses/by/4.0/. 


\begin{abstract}
(Continued from previous page)
Conclusion: Our results show the extent of purity loss when inadequate attention is paid to the preservation of seed purity. Pure conventional seeds could vanish in Burkina Faso, while Bt seeds do not carry the combination of the expected Bt traits. Any country wishing to embark on the use of Bt cotton, or to resume its use, as in the case of Burkina Faso, must first adjust its national seed production scheme to ensure that procedures to preserve varietal purity are enforced. The preservation of varietal purity is necessary to enable the launch or the continuation of identity-cotton production. In addition, the preservation of varietal purity is necessary to ensure the sustainable effectiveness of Bt cotton. In order to ensure that procedures to preserve varietal purity are observed, seed purity must be tested regularly, and test results must be published.
\end{abstract}

Keywords: Conventional cotton, Organic cotton, GM cotton, Seed production scheme, Seed control, Burkina Faso

\section{Background}

Since the commercial release of geneticallymodified (GM) cotton designed to provide resistance to some damaging insects in 1996, the issue of seed purity has received little attention and mainly with regard to the potential for cross-pollination between genetically modified organism (GMO) and non-GMO seeds because of the concerns of producers of identity-cotton, especially organic cotton. Producers of organic cotton are concerned that they will not being able to meet the requirement for the absence of GM traits at a stated threshold (Cederholm 2014). In the USA, the coexistence of GM and non-GM crops is perceived as an illusion because the contamination by GM crops is thought to be impossible to escape (Food Democracy Now! 2014), so the continuation of organic cotton production is threatened.

However, published studies dealing with the purity of GM cotton seeds, more precisely Bt cotton seeds, are rare. Many studies have dealt with the expression of Bt genes in varieties by measuring the concentration of Bt toxins. For instance, the variety effect or seed generation effect has been observed in India where $F_{1}$ hybrids are released, and the $F_{2}$ offspring might have been used by farmers (Singh et al. 2016). The issue of the purity of Bt-cotton seeds has only been specifically addressed in Pakistan, where discrepancies were found between farmers' declarations of the types of cotton they were growing and the real typechecked through laboratory analysis of plant samples, in a context where only the single Cry1Ac gene was encountered (Spielman et al. 2017). Even in studies about the issue of coexistence, the rate of contamination of supposed non-GM seeds with GM traits is addressed, from $0.1 \%$ to $5.0 \%$, but the purity of GM seeds is seldom mentioned. GM traits are not considered distinct from other genetic traits for which the general genetic purity should be met, at a level generally established at $95.0 \%$ to $99.9 \%$, depending on the type of seeds in the USA or Europe. The standard GM purity rate is established at $90 \%$ in China (Seed world 2017), and 90\% 95\% in India (Mohan and Sadananda 2019).
The lack of work on the purity of Bt-cotton seed varieties is regrettable because of the implications for the effectiveness and sustainability of Bt-cotton. As shown by Sun et al. (2013), when conventional seeds account for $20 \%$ to $50 \%$ of the seeds in a packet of supposed Bt seed, poor or very poor pest control is achieved. Although the presence of conventional seeds in a mixture might produce a kind of refuge within a plot, such a type of refuge was found ineffective (Tabashnik 1994) and the development of resistance was promoted (Brévault et al. 2015), while good stewardship is required for the success of its implementation (Mohan and Sadananda 2019).

The objective of this paper is to compensate for the mentioned lack of investigation of seed purity for both conventional and Bt varieties. This paper is based on data collected in 2015 in Burkina Faso, on the eve of a decision to suspend the use of Bollguard 2 (BG2) varieties (varieties with two stacked $\mathrm{Bt}$ genes, Cry1Ac and $C r y 2 A b)$. Bt cotton was legally released in Burkina Faso in 2008. The data corresponded to enzyme linked immunosorbent assay (ELISA) tests conducted to assess the presence of Cry $1 A c$ and $C r y 2 A b$ genes in samples of seeds from 646 fields representing nearly equally the conventional variety (FK37) and the Bt variety (FK95 $\mathrm{BG} 2$, derived from the introgression of the two main $\mathrm{Bt}$ genes into FK37). The knowledge gained with regard to the level of seed purity and factors influencing seed purity should be helpful to other developing countries preparing to embark on the use of Bt-cotton. This study will also be useful to Burkina Faso in the event a decision is taken to resume the use of Bt cotton.

\section{Results}

Because of the organization of seed distribution in Burkina Faso, fields could be easily classified according to the types of seeds supplied to farmers. Seeds were supplied by Sofitex, the main cotton company representing $80 \%$ of national production, after registering what each farmer wanted to grow, although some arbitration might occur according to seed availability. In general, farmers do not get seeds outside the cotton company in their 
area, although there might be some arrangement between individuals to get additional seeds from each other. Hence, sampling for our study was based on the records of the extension specialists working for Sofitex.

With reference to the results of ELISA tests on the samples from fields cultivated with conventional seeds supplied by Sofitex, the presence of Bt genes was clearly revealed (Table 1). As cotton is mainly an autogamous species (self-pollinating), the results illustrate the extent of contamination of conventional varieties with Bt genes in seeds supplied to farmers.

Out of 297 fields cultivated with so-called conventional seeds, $63.6 \%$ and $59.3 \%$ showed the presence of $C r y 1 A C$ and $C r y 2 A b$, respectively. In both cases, more than $40 \%$ of seeds in a sample (4 to 5 seeds out of 11 ) tested positive for the Bt genes. Both Bt genes were detected in $52.2 \%$ of the conventional cotton fields, indicating that about half of the sampled fields were indeed Btcotton fields.

In other words, of the 297 fields where conventional cotton was supposedly cultivated, less than half contained conventional cotton. As shown in Table 2, only $29.3 \%$ of the fields labeled as conventional were actually conventional, $52.2 \%$ of the fields contained BG2 cotton, $11.4 \%$ of the fields contained the Cry1Ac gene, and $7.1 \%$ of fields contained cotton with the $C r y 2 A b$ gene.

Conversely, in the 349 fields where cotton varieties labeled as Bt were cultivated, $95 \%$ of the fields exhibited the presence of either the Cry1Ac or the Cry $2 A b$ gene in at least $46 \%$ of the seeds sampled from each field (Table 3). Further, $92.6 \%$ of the fields labeled as Bt contained cotton with both genes in at least $46 \%$ of the seeds sampled, and more than $86 \%$ of all seeds tested (or more than 9 out of 11 seeds) contained both Bt genes. Even if the criterion for the presence of Bt genes was increased to $73 \%$ of seeds tested, $65 \%$ to $77 \%$ of fields that were sampled met the standard to be labeled as Bt cotton (results not shown in either table).
Table 2 Contamination status of conventional seeds in samples from conventional cotton fields (\% of 297 samples)

\begin{tabular}{|c|c|c|c|}
\hline \multirow{2}{*}{$\begin{array}{l}\text { Contamination }^{\mathrm{a}} \\
\text { by Cry } 1 A c\end{array}$} & \multicolumn{2}{|c|}{ Contamination $^{\mathrm{a}}$ by $\mathrm{Cry} 2 \mathrm{Ab} / \%$} & \multirow{2}{*}{$\begin{array}{l}\text { Total / } \\
\%\end{array}$} \\
\hline & No & Yes & \\
\hline No & 29.3 & 7.1 & 36.4 \\
\hline Yes & 11.4 & 52.2 & 63.6 \\
\hline Total & 40.7 & 59.3 & 100.0 \\
\hline
\end{tabular}

However, it would be more difficult to claim that Btcotton fields were cultivated with pure Bt seeds, defined as fields in which more than $95 \%$ of seeds exhibited $\mathrm{Bt}$ genes (Table 4). The criterion for pure seeds was met for less than $60 \%$ of the Bt fields when each Bt genes was considered separately, and only $40 \%$ of fields contained seeds in which $95 \%$ or more exhibited both $\mathrm{Bt}$ genes simultaneously.

If the criterion for seed purity of $95 \%$ is applied to define the status of cotton grown in a particular field, $27.2 \%$ of the fields that were supposedly planted to BG2 varieties were in fact fields of conventional cotton (Table 5). Only $40.4 \%$ of the fields planted to the BG2 variety were actually BG2 fields, and $32.4 \%$ of fields planted with varieties that supposedly contained both Bt genes had cotton with only one gene (19.2\% were Cry1Ac and $13.2 \%$ were $\mathrm{Cry} 2 \mathrm{Ab}$ ).

\section{Discussion}

There is little information in the literature to confirm our results on the purity of Bt-cotton seeds. Seed organizations should disclose such information they must have, but they do not. Consequently, deficiencies in seed purity are documented in only a few countries.

In Pakistan, the lack of seed purity for both conventional and Bt cotton has been assessed by comparing farmers' declarations on the types of seeds they have planted with biochemical analysis of plant leaves. It was found that only Bt cotton with a single gene $(\mathrm{Cry} 1 \mathrm{Ac})$

Table 1 Presence of Bt genes in seeds from fields cultivated with conventional variety

\begin{tabular}{|c|c|c|c|}
\hline & Presence of Cry1Ac & Presence of $C r y 2 A b$ & Double genes presence \\
\hline Number of sample & 297 & 297 & 297 \\
\hline Share of samples with presence ${ }^{a}$ of the concerned Cry gene /\% & 63.5 & 59.3 & 52.2 \\
\hline \multicolumn{4}{|l|}{ Presence rate ${ }^{\mathrm{b}}$ of $\mathrm{Cry} 7 \mathrm{Ac} / \%$} \\
\hline Mean & 41.5 & & 43.1 \\
\hline Std. deviation & 23.2 & & 22.5 \\
\hline \multicolumn{4}{|l|}{ Presence rate ${ }^{b}$ of $C r y 2 A b / \%$} \\
\hline Mean & & 39.3 & 40.3 \\
\hline Std. deviation & & 23.2 & 23.3 \\
\hline
\end{tabular}

${ }^{a}$ Presence was claimed when observed on at least one out of 11 seeds of each sample

${ }^{b}$ Rate of presence in samples where the presence was observed according to the retained criterion, calculated from the number of seeds with Bt gene detected out of eleven 
Table 3 Bt status of seeds in samples from fields of Bt cotton

\begin{tabular}{|c|c|c|c|}
\hline & Cry1Ac & Cry2Ab & Cry1Ac+Cry2Ab \\
\hline Number of sample & 349 & 349 & 349 \\
\hline Share of samples with presence ${ }^{a}$ of the concerned Cry gene /\% & 95.7 & 94.3 & 92.6 \\
\hline \multicolumn{4}{|l|}{ Presence rate $^{\mathrm{b}}$ of CrylAc $1 \%$} \\
\hline Mean & 88.1 & & 88.8 \\
\hline Std. deviation & 11.9 & & 11.2 \\
\hline \multicolumn{4}{|l|}{ Presence rate ${ }^{\mathrm{b}}$ of $\mathrm{Cry} 2 \mathrm{Ab} / \%$} \\
\hline Mean & & 86.5 & 86.6 \\
\hline Std. deviation & & 12.2 & 12.1 \\
\hline
\end{tabular}

a Presence is claimed when observed on no less than 6 seeds out of 11 of each sample

${ }^{b}$ Rate of presence in samples where the presence was observed according to the retained criterion, calculated from the number of seeds with Bt gene detected out of eleven

was cultivated, $11 \%$ of the farmers who believed they were cultivating $\mathrm{Bt}$ cotton were cultivating cotton without the Bt gene, and $5 \%$ of the farmers who believed they were cultivating non-Bt cotton were, in fact, growing cotton with the Bt gene (Spielman et al. 2017). The percentage discrepancies in our study of cotton in Burkina Faso are higher than those in Pakistan; the fact that a double-Bt gene cotton was used in Burkina Faso could be an explaining factor. The authenticity of the seeds supplied only by Sofitex, the major cotton company in the country, should be better.

In China, Pemsl et al. (2005) measured the level of Bt toxins in plant tissues and found a probable lack of seed purity in Bt cotton varieties. In the case of hybrid varieties developed for cultivation in the southern provinces of China, a lack of seed purity was also tested indirectly through the assessment of the presence of Bt toxins (Xu et al. 2008). In both cases dealing with traditional cotton production areas in the Eastern and Southern regions of China, the extent of purity imperfection was not estimated. Since 2010, five-sixths of cotton production in China has shifted towards the region of Xinjiang in the North-West (Lu et al. 2018; Ma et al. 2020; Yu 2013), because of better labor productivity (Zhu 2013).
Although Bt cotton was cultivated by $52 \%$ of cotton growers in Xinjiang in 2012 (Li et al. 2014), the issue of seed purity has been little addressed and was not even mentioned in a recent assessment of the use of transgenic cotton in this region (Li et al. 2019).

In Burkina Faso, Sofitex controls the production of all seeds, including the FK95 BG2 variety, but the company does not provide data on seed purity. Such information has been made available by a single initiative to check the $\mathrm{Bt}$ status of plants labeled as Bt. Out of a preliminary test of 45 samples, $24.4 \%$ had no Bt genes at all, $17.8 \%$ had a single Bt gene (equally distributed between the two main Bt genes), and 57.8\% had both Bt genes (Fok et al. 2016). These figures are quite consistent with those in our present study, which is based on a much higher number of samples.

The literature dealing with the phenomenon of contamination of conventional seeds by Bt genes is larger, but with much less, if any, quantitative assessment compared with our study. The documentation of the issue of contamination of conventional seeds with Bt genes is greater mainly because the phenomenon has endangered the continuation of organic cotton production, notably in the USA (Hershaw 2013), where it is claimed that no

Table 4 Purity status of Bt seeds in samples from Bt-cotton fields

\begin{tabular}{|c|c|c|c|}
\hline & $\begin{array}{l}\text { Presence } \\
\text { of Cry1AC }\end{array}$ & $\begin{array}{l}\text { Presence } \\
\text { of } C r y 2 A b\end{array}$ & $\begin{array}{l}\text { Double } \\
\text { genes } \\
\text { presence }\end{array}$ \\
\hline Number of sample & 349 & 349 & 349 \\
\hline Share of samples corresponding to fields grown from pure ${ }^{a}$ seeds for the concerned Cry gene $/ \%$ & 59.6 & 53.6 & 40.4 \\
\hline \multicolumn{4}{|l|}{ Rate $^{b}$ of CrylAc presence in the samples corresponding to fields grown from pure seeds for this gene $/ \%$} \\
\hline Mean & 96.0 & & 96.7 \\
\hline Std. deviation & 4.5 & & 4.4 \\
\hline \multicolumn{4}{|l|}{ Rate $^{b}$ of CryzAb presence in the samples corresponding to fields grown from pure seeds for this gene $/ \%$} \\
\hline Mean & & 95.4 & 95.9 \\
\hline Std. deviation & & 4.6 & 4.5 \\
\hline
\end{tabular}

a Purity is claimed when the presence of Bt gene was observed on no less than 10 seeds out of 11 of each sample

${ }^{b}$ Rate calculated by the number of seeds with Cry gene detected out of eleven of each sample 
Table 5 Bt status of seeds in Bt-cotton fields

\begin{tabular}{|c|c|c|c|}
\hline \multirow{2}{*}{$\begin{array}{l}\text { Cry1Ac } \\
\text { status }^{a}\end{array}$} & \multicolumn{2}{|c|}{ Cry2Ab status $^{\mathrm{a}} / \%$} & \multirow{2}{*}{$\begin{array}{l}\text { Total / } \\
\%\end{array}$} \\
\hline & No & Yes & \\
\hline No & 27.2 & 13.2 & 40.4 \\
\hline Yes & 19.2 & 40.4 & 59.6 \\
\hline Total & 46.4 & 53.6 & 100.0 \\
\hline
\end{tabular}

${ }^{\text {a }}$ Status refers to the use of pure seeds, i.e. presence on at least $90 \%$ of the tested seeds in samples, or on at least 10 out of 11 seeds of each sample

organic cotton producer could meet the purity criterion for conventional seeds. In the United States, the contamination of conventional seeds has become so widespread and unavoidable that Endres (2005) advocated a revision of the federal and state laws governing seed purity. In India, in almost $30 \%$ of cases examined, conventional seeds supplied to plant a refuge contained Bt genes (S. Kranthi et al. 2017), although to a non-specified extent. In Burkina Faso, a study mandated by promoters of organic cotton pointed out that about $50 \%$ of organic cotton producers were provided with seeds containing $\mathrm{Bt}$ genes. However, the criterion for declaring the presence of a Bt gene in conventional seeds was very stringent; $\mathrm{Bt}$ genes were declared present if just one out of 300 seeds was found to contain such a gene in tests completed with lateral flow strips (Vognan and Bourgou 2014).

Our results clearly showed that on the eve of suspending the use of Bt-cotton, conventional seeds were contaminated to a large extent. Further, since we utilized a rather forgiving threshold to declare the presence of $\mathrm{Bt}$ genes in conventional seeds, the real situation of contamination was almost surely worse than indicated in our figures.

The main reason for the contamination of conventional varieties with Bt traits was the lack of specific attention to prevent contamination when Bt cotton was disseminated on a large scale in 2009. No specific measures were implemented to delineate a non-Bt cotton zone where conventional seed production could have taken place.

In addition, farmers commonly exchange seeds among themselves, including farmers operating in seed production areas, leading inevitably to the comingling of conventional and Bt cotton varieties. Even farmers who did not wish to grow Bt cotton would have inadvertently received seeds with Bt traits.

Quality control regarding the Bt traits in seed production was quantitatively insufficient. ELISA tests were conducted by Sofitex (Sofitex 2008), but the purpose of the tests was to check the Bt nature of seeds, not the level of Bt genes present in seeds.

Since the suspension of the use of Bt cotton in Burkina Faso in 2016, the level of contamination of conventional cotton with Bt genes has probably declined from the quite high level found in our study. Nevertheless, it is unlikely that Bt genes have disappeared from fields. After the suspension decision, seed control was implemented with more stringent measures. The main cotton variety in Burkina Faso also shifted to another conventional one. However, the variety shift could not be implemented completely in one campaign, and there must remain some level of adventitious and unintentional presence of Bt genes in cotton fields. So, to some extent, cotton producers, including producers of organic cotton, keep benefitting from some effectiveness of Bt genes to control targeted pests.

On the eve of the suspension of the use of Bt cotton, the pest resistance traits of the Bt cotton seeds could be acknowledged, although the expression of those traits was not perfect. Our point is that, based on ELISA tests, Bt toxins were detected in Bt varieties, but not at the levels expected. The fact that the presence of Bt proteins in Bt varieties was lower than expected could lead to the inference that Bt genes were absent, but this inference would be excessive because many factors affect the expression levels of Bt genes (Huang et al. 2014; Iqbal et al. 2013; Rochester 2006; Wan et al. 2005). Besides, this argument has little application to our study because we observed this expression in falsely-labeled conventional seeds in the same growing conditions.

Our work is the first to quantify the degradation of the status of BG2 seeds to such a poor level. The BG2 status (based on the presence of both $C r y 1 A c$ and $C r y 2 A b$ genes) applied to only $40 \%$ of the seeds sampled. Again, because of the conservative threshold retained for purity regarding the presence of Bt genes in seeds, the real lack of BG2 status was even worse than indicated by our figures.

At least two factors explained the lack of Bt purity in seeds. First, there was insufficient control of the BG2 status of seeds at the stage of seed production and processing, and the failure of Sofitex to implement specific actions to protect the varietal purity of seeds was to blame. However, there was a second and even more important factor. The seeds for large scale release originally provided by Monsanto were not sufficiently pure because the time allowed for the production of seed varieties with Bt traits in Burkina Faso was too short (Bourgou et al. 2020; Fok 2016). It was technically impossible to achieve stabilized and homogenous seeds in 2 years with at most four production cycles. The lack of purity in the seeds originally supplied to Burkina Faso, after introgression of Bt genes, made subsequent efforts at quality control more difficult and costly. This deficiency in the provision of the original seeds after introgression of Bt genes- not reported so far in other countries should be regarded as the principal factor explaining the poor BG2 status of Bt cotton seeds. 
The cultivation of Bt-cotton with insufficient purity has worrisome implications for the effectiveness and sustainability of the Bt technology against target pests. The mixture in an environment of cotton varieties with varying degrees of inclusion of $\mathrm{Bt}$ genes, ranging from seeds with neither gene, seeds with Cry1Ac only, seeds with $\mathrm{Cry} 2 \mathrm{Ab}$ only, and seeds with both genes, creates difficulties in pest management and the avoidance of the development of resistance and wipes out the rationale for having adopted the stacked gene technology in the first place.

The presence of seeds with a single Bt gene creates a condition favorable for the emergence of resistance to that gene, hence facilitating the emergence of resistance to seeds that contain both Bt genes. Likely, the process of resistance build-up against both Bt genes had already started in Burkina Faso by 2015, and insects with resistant alleles could probably be encountered by that time, at least at low frequencies. If this was the case, then the effectiveness of the same genes cannot be guaranteed if Bt cotton is relaunched in Burkina Faso. In addition, there would also be the risks associated with the outbreak of secondary pests that are encountered in most (if not all) countries having adopted Bt-cotton for a few years (Zhao et al. 2011; Kranthi 2011; Fok 2010).

\section{Conclusions}

On the eve of suspending its use of Bt cotton, Burkina Faso had suffered from the loss of purity in the seeds of both conventional and Bt varieties. The situation resulted from a failure to adjust the seed production and distribution scheme when Bt cotton was originally released, and from the lack of purity in the original Bt seeds supplied to the country. So, any country wishing to release varieties with Bt genes should first ensure the genetic purity of the seeds it receives. Secondly, the country must adjust its scheme of seed production and distribution to protect the genetic identity of future seed generations. Third, it is necessary to check varieties for seed purity regularly, and such data must be shared with all stakeholders.

These lessons also apply to Burkina Faso in case the country decides to resume the use of Bt cotton. The effectiveness of Bt cotton in Burkina Faso may be hampered by the legacy of resistance among target pests that began to be developed during the first period of Bt use.

\section{Methods}

The data were collected in December 2015 in the framework of a study to access the gap in fiber quality between the conventional and Bt cotton varieties being cultivated at this period (Bourgou et al. 2020). The gap observed, at the expense of the Bt-cotton variety, has implied huge financial loss for the cotton companies (Fok 2016) which led to a decision in mid-2015 to suspend the Bt-cotton use (Dowd-Uribe and Schnurr 2016). The 2015 season was the last where both conventional and $\mathrm{Bt}$, isogenic cotton varieties were grown.

The conventional variety was known as FK37, developed by the national research in Burkina Faso while the transgenic variety was FK95 BG2 obtained via introgression of two Bt genes (Cry1Ac and Cry2Ab) implemented by Monsanto. It is worthwhile to note that FK37 was supplied for introgression in 2004, and seeds of FK95 BG2 after two backcrosses were sent back in 2006 for demonstration of biological effectiveness before release on a large scale in 2008. The supplied seeds were obtained after at most four cycles (by cultivation in both northern and southern hemispheres), quite insufficient for a stable and homogenous genetic material.

For the mentioned study, sample collection was conducted in districts over the whole intervention area of Sofitex, representing about $80 \%$ of total production (Fig. 1). Three cotton producer groups (CPG) were randomly selected by the district and then three producers per CPG. Within CPG, fields of producers growing both types of cotton were sampled preferentially; they were complemented by producers growing one of the two types. In the 2015 season, most farmers planted Bt-cotton $(62.53 \%$ of the total $520428 \mathrm{hm}^{2}$ ), consequently, the share of FK95 BG2 in sampled fields was higher $(54.00 \%$ and $46.00 \%$ for FK95 BG2 and FK37, respectively).

In each field, a sample of $1 \mathrm{~kg}$ of seed cotton was collected randomly from 135 cotton plants across diagonal lines of the field. A total of three bolls was picked at the bottom, in the middle, and on top of each plant. After ginning, eleven seeds were randomly isolated to undergo ELISA test and check the presence or not of Cry1Ac and $\mathrm{Cry} 2 \mathrm{Ab}$, according to the procedures followed at the seed quality control lab of Sofitex (Sofitex 2008) and probably set up in line with Monsanto stewardship.

For each field sample, the presence of Bt genes was controlled for each of eleven seeds but the data we highlighted were the percentages of seeds that tested positive (e.g., 9.09\% means one seed tested positive out of eleven). For each sample, separated figures were obtained for the presence of Cry1Ac and Cry2Ab.

In our study, we considered the so-called conventional cotton field cultivated with seeds to be contaminated by a Cry gene when the corresponding sample showed an ELISA test result above 10\% (or ELISA test was positive for more than one out of eleven seeds). Conversely, we considered a so-called Bt-cotton field to be cultivated with pure seeds with regard to a specific Cry gene when the ELISA result of the corresponding sample was above $90 \%$ (or test positive for at least 10 out of 11 seeds). In other words, we retained a maximum threshold of $10 \%$ of Cry gene presence to approve the purity of conventional seeds 




Fig. 1 Sofitex cotton zone, showing study sampled districts and sites

and a minimum threshold of $90 \%$ for that of Bt cotton seeds. These thresholds are much higher than those commonly referred to in the USA or Europe, at 1.0\% 5.0\% and $95.0 \% \sim 99.0 \%$, respectively, and which are quite stringent and hard to achieve in practice. The thresholds we retained are consistent with a conservative approach to shelter from false-positive or false-negative errors (Remund et al. 2001). Our purpose is to show the loss of purity, which would be furthermore real when following a more stringent criterion of seed purity.

However, a field might be considered to have a Btcotton status even if the seeds used were not pure as defined above. This is a situation seldom addressed as it is assumed that GM seeds being supplied are necessarily pure. For a first study taking into account the possibility of growing Bt cotton with seeds which are not pure, we have retained a minimal threshold of $46 \%$ of Bt gene presence in seeds (in our case, presence in at least 6 out of 11 seeds) to assume that supplied seeds were of Bt nature.

\section{Acknowledgements}

We thank DIANE K. Sidiki for helping in data handling and organization. We also thank OUATTARA B. Marcel for helping to design and draw the map showing Sofitex cotton zone and sites sampled. We are grateful to TOWNSEND Terry of Cotton Analytics for his interest in the topic in the text and for polishing it.

\section{Authors' contributions}

Bourgou $L$ conceives and supervises sample collection in fields, processes data of ELISA tests, and co-write the manuscript; Kargougou E supervises the implementation of ELISA tests, manages and processes the data obtained; Sawadogo $\mathrm{M}$ conceives the study design and the sample collection in the field; Fok $\mathrm{M}$ formats the results from the data processing of ELISA tests, conceives and write the manuscript. All authors have approved the manuscript before submission.

\section{Funding}

The study was implemented on request of the interprofessional body of the cotton sector in Burkina Faso (AICB) with the allocation of a specific fund.

\section{Availability of data and materials}

The datasets generated and/or analyzed during the current study are not publicly available due to their collation in the framework of a private study requested by the interprofessional body of the cotton sector in Burkina Faso (AICB) but are available from the corresponding author on reasonable request.

Ethics approval and consent to participate

Not Applicable.

Consent for publication

Not Applicable.

\section{Competing interests}

The authors declare that they have no competing interests.

\section{Author details}

'INERA, Programme Coton, BP 208, Bobo-Dioulasso, Burkina Faso. ${ }^{2}$ SOFITEX, Laboratoire Contrôle Qualité Semences, 01 BP 147, Bobo-Dioulasso 01 Burkina Faso. ${ }^{3}$ Université Ouaga1 Joseph Ki-Zerbo, 09 BP 848, Ouagadougou 09, Burkina Faso. ${ }^{4}$ CIRAD, F-34398 Montpellier, France. ${ }^{5}$ UPR AIDA, Univ Montpellier, Montpellier, France. 
Received: 17 July 2020 Accepted: 24 September 2020

Published online: 11 November 2020

\section{References}

Bourgou L, Hema SO, Koulibaly B, et al. Impact of transgenic conversion on the characteristics of Burkina Faso cotton. Afr J Biotechnol. 2020;19(1):8-17. https://doi.org/10.5897/AJB2019.16907.

Brévault T, Tabashnik EB, Carrière Y. A seed mixture increases dominance of resistance to Bt cotton in Helicoverpa Zea. Sci Rep. 2015;5:1-7. https://doi.org/ 10.1038/srep09807

Cederholm H. Protecting organic seed integrity. The organic farmer's handbook to GE avoidance and testing. Portland: Organic Seed Grower and Trade Association (OSGATA); 2014.

Dowd-Uribe B, Schnurr AM. Briefing: Burkina Faso's reversal on genetically modified cotton and the implications for Africa. Afr Aff. 2016;115(458):161-72. https://doi.org/10.1093/afraf/adv063.

Endres AB. Revising seed purity laws to account for the adventitious presence of genetically modified varieties: A first step towards coexistence. J Law Policy. 2005:1(479):131-63. https://nationalaglawcenter.org/wp-content/uploads/ assets/articles/endres_seedpurity.pdf . Accessed 14 Sep 2020.

Fok M. Gone with the wind of transgenic cotton use in the United States a vision of the discussions and presentations at the New Orleans (Louisiana, USA) 'Beltwide cotton conferences' in January 2010. Cahiers Agric. 2010;19(4):2928. https://doi.org/10.1684/agr.2010.0406 (in French).

Fok M. Financial impacts of Bt-cotton for cotton companies and growers in Burkina Faso. Cahiers Agric. 2016;25(3):1-13 (in French). https://doi.org/10. 1051/cagri/2016020

Fok M, Claire N, Alain R, Dominique D. Feasibility study of GM cotton in Cote d'Ivoire. Montpellier: CIRAD; 2016 (in French). Report available on request to https://firca.ci/.

Food Democracy Now!. Coexistence equals contamination: Tell the USDA to stop Monsanto' s GMO contamination. 2014. https://www.fooddemocracynow. org/blog/2014/mar/3/tell_the_USDA_2_stop_Monsantos_GMO_ contamination/. Accessed 25 June 2016

Hershaw E. Back to mobile seeds of discontent: A Texas organic cotton farmer takes on Monsanto. 2013. http://www.texasobserver.org/seeds-ofdiscontent/ . Accessed 16 Apr 2014.

Huang JK, Mi JW, Chen RJ, et al. Effect of farm management practices in the Bt toxin production by Bt cotton: evidence from farm fields in China. Transgenic Res. 2014;23(3):397-406. https://doi.org/10.1007/s11248-0139775-7.

lqbal A, Ali S, Zia M, et al. Comparative account of bt gene expression in cotton under normal and salt affected soil. Int J Agric Biol. 2013;15(6):1181-6.

Kranthi K. 10 years of Bt in India, Part III. Cotton grower. 2011. https://www. cottongrower.com/crop-inputs/seed-traits/part-iii-10-years-of-bt-in-india/ . Accessed 20 June 2012

Kranthi S, Satija U, Pusadkar P, et al. Non- Bt seeds provided by seed companies in India - are they suitable as refuge for Bt- cotton? Curr Sci. 2017;112(10): $25-6$.

Li XY, Gong ZL, Wang JD, et al. The planting intentions investigation and policy suggestion of transgenic insect resistant cotton in Xinjiang. Cotton Sci. 2014; 36(6):2095-3143.

Li XY, Wang JN, Liang YJ, et al. Review and proposals of transgenic Bt cotton in Xinjiang. China Cotton. 2019;46(8):4-5. https://doi.org/10.11963/1000-632X. Ixylxy.20190815

Lu XR, Jia XY, Niu JH. The present situation and prospects of cotton industry development in China. Sci Agric Sin. 2018;51(1):26-36. https://doi.org/10. 3864/j.issn.0578-1752.2018.01.003.

Ma CY, Mamat S, Yao J, Gulnur I. Spatio-temporal changes of cotton production in China from 1950 to 2015. Acta Geograph Sin. 2020:75(8):1699-710.

Mohan K, Sadananda AR. Success of refuge-in-bag for Bt-cotton hinges on good stewardship. Curr Sci. 2019;117(5):739-40. https://doi.org/10.1371/journal. pone.0021863.8.

Pemsl D, Waibel H, Gutierrez A. Why do some Bt-cotton farmers in China continue to use high levels of pesticides. Int J Agri Sustainability. 2005;3(1): 44-56. https://doi.org/10.11821/dlxb202008010.

Remund K, Dixon D, Wright D, Holden L. Statistical considerations in seed purity testing for transgenic traits. Seed Sci Res. 2001;11:101-19. https://doi.org/10. 1079/SSR200166.
Rochester I. Effect of genotype, edaphic, environmental conditions, and agronomic practices on Cry1Ac protein expression in transgenic cotton. J Cot Sci. 2006;10:252-62.

Seed World. Variety Certification Standard Committee: Certification standard of varieties of main crops at national level (in Chinese). 2017. https://m.sohu. com/a/158948011_266055. Accessed 23 Mar 2020.

Singh BP, Sandhu SS, Kalia VK, et al. Assessment of Bt trait purity in different generations of transgenic cottons. Indian J Exp Biol. 2016;54(4):237-44.

Sofitex. Procedures for the specific tests of quality control of Bt seeds. BoboDioulasso: Sofitex Seed Control Laboratory; 2008. p. 6. (in French).

Spielman D, Zaidi F, Zambrano $P$, et al. What are farmers really planting? measuring the presence and effectiveness of Bt cotton in Pakistan. PLoS One. 2017;12(5):1-10. https://doi.org/10.1371/journal.pone.0176592.

Sun GQ, Zhang R, Wang Y, et al. Influence of seed purity on insect resistance and yield in transgenic cotton. Curr Biotechnol. 2013;5(1):27-31. https://doi.org/ 10.3969/j.issn.2095-2341.2013.01.06.

Tabashnik B. Delaying insect adaptation to transgenic plants: seed mixtures and refugia reconsidered. Proc R Soc B. 1994;255:7-12. https://doi.org/10.1098/ rspb.1994.0002.

Vognan G, Bourgou L. Study report on the contamination of organic cotton by GM cotton. Bobo-Dioulasso: INERA; 2014. p. 63. (in French).

Wan P, Zhang YJ, Wu KM, Huang MS. Seasonal expression profiles of insecticidal protein and control efficacy against Helicoverpa armigera for Bt cotton in the Yangtze River valley of China. J Econ Entomol. 2005;95(1):195-201. https:// doi.org/10.1093/jee/98.1.195.

Xu NY, Fok M, Bai LX, Zhou ZG. Effectiveness and chemical pest control of Btcotton in the Yangtze River valley. China Crop Prot. 2008;27:1269-76. https:// doi.org/10.1016/j.cropro.2008.04.003.

Yu SX. Present situation and development trend of cotton production in China. Eng Sci. 2013;15(4):9-13.

Zhao JH, Ho P, Azadi H. Benefits of Bt cotton counterbalanced by secondary pests? perceptions of ecological change in China. Environ Monit Assess. 2011;173(1-4):985-94. https://doi.org/10.1007/s10661-010-1439-y

Zhu HY. The underlying cause for the concentration of China's cotton production in Xinjiang. Geogr Res. 2013:32(4):744-54. https://doi.org/10.11821/ yj2013040017.
Ready to submit your research? Choose BMC and benefit from:

- fast, convenient online submission

- thorough peer review by experienced researchers in your field

- rapid publication on acceptance

- support for research data, including large and complex data types

- gold Open Access which fosters wider collaboration and increased citations

- maximum visibility for your research: over $100 \mathrm{M}$ website views per year

At BMC, research is always in progress.

Learn more biomedcentral.com/submissions 